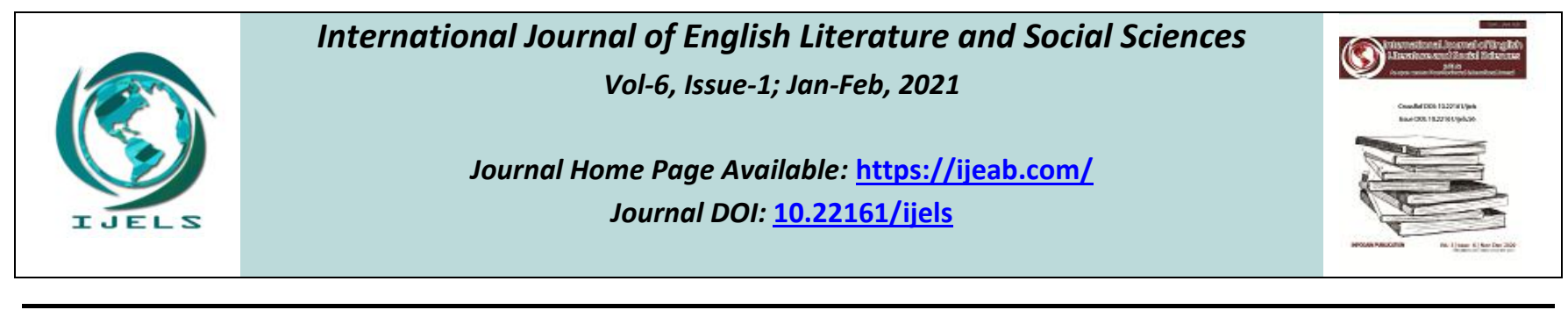

\title{
Theorization of Animal Studies and Re-reading White
} Fang

\author{
Harshita U Urs
}

Department of English, Sivananda Sarma Memorial RV College, Bangalore, India

Received: 03 Nov 2020; Received in revised form: 30 Dec 2020; Accepted: 07 Jan 2021; Available online: 14 Jan 2021 (C)2021 The Author(s). Published by Infogain Publication. This is an open access article under the CC BY license (https://creativecommons.org/licenses/by/4.0/).

\begin{abstract}
The recent advances in technology has paved way for deconstruction of the concepts like human being, humane and humanity. These are conventional forms of looking at the 'self' and the 'other'. Post structural theorists and many Marxist thinkers have critiqued the construction of the 'other-ness.' Similarly, anthropocentrism questions and debates the conception of human (self) and the animal (other) is produced and understood. Donna Haraway's cyborg gives a jolt to the epistemology of the self. ${ }^{1}$ It contrasts the mechanized AI or humanoid with a virtue that alters the centrality of the human being. Thus, 'Animal Studies' investigates the human attitude towards the treatment of other animals. There are numerous graphics, films, animations, comics, texts, etc. that talk about the human- animal relationship. However, Jack London`s White Fang is used to analyze the human attitude towards wolf dog and thereby understand the conception of self and the other. The aim of this paper is to understand what makes human beings identify themselves superior and animals inferior. This question becomes important especially, when one reads the post humanist critique of humanism and its legacy. It challenges the human subjectivity and embodiment. ${ }^{2}$ Though animals share the human legacy of creation and evolution, they are traumatized and ill-treated. Due to human cruelty and pollution has altered the habitat and food chain of most spices, that is, anthropocene. Animal studies revisits the position of animals in literature. Nonetheless, we witness that cruelty towards women or cruelty towards animals are due to the fact that man or the human being in the latter instance, is the nucleus of the discourse.
\end{abstract}

Keywords-Animal Studies, Anthropocentrism, Anthropocene Cyborg, Post Humanism.

\section{INTRODUCTION}

With Cultural studies the way we look at the world has changed. The variants of this branch of study is animal studies and post humanism. The work attempts to examine the status of non-human species in the human scheme of existence. It demonstrates the ways in which Canis lupus (Dogs) have evolved to be companions to Homo sapiens. It tries to probe the fact that, humans have engaged in an anthropocentric discourse. That is, animals at the rim of existence and human beings at the heart of the discourse. Donna Haraway`s When Species Meet describes three historical injuries to the primary narcissism of the selfcentred human subject. ${ }^{1}$ Such perceptions have caused much worry to animal rights activists who fear that the animal-man crisis may lead to severe ecological imbalance. Through the image of the 'anthropocene' the work sensitises one to the idea of harmonious coexistence.

The emergent discipline of 'Animal Studies' investigates the human attitude towards the treatment of other animals. Before the 2000s, Humanities and Social Sciences paid less attention to the participation of nonhuman animals in human cultures. Now various academic disciplines are in the process of executing an 'animal turn', that questions the ethical and philosophical grounds of human exeptionalism by taking seriously the animal presence that haunts the margins of history, anthropology, philosophy, sociology and literary studies. ${ }^{2}$ Instances of such works are grouped under the umbrella term "Animal 
Studies". It is an interdisciplinary project whereby the primary motivation is to animalise canons of literature by rethinking the representation of animals.

Taking cues from Animal Studies and recognising the importance of the representation of animals in literature, in order to understand the course of human culture, this study examines the representation of the canine(wolf-dog) in Jack London's work White Fang. The hypothesis is that in many of the novels, even though the dog's role is central, the treatment meted out to it, is not as a 'Companion Species', but as a subordinate species that can be controlled and used for human benefit. The perspective adopted here for analysis is critical of human intervention and attitude. The article aims to test Jack London's White Fang from the viewpoint of Animal Studies. White Fang deals with the domestication of a wild wolf-dog. The examination posits how dogs in animal fiction are objectified. The frames for the study is taken from Donna Haraway`s When Species Meet where she claims dogs to be 'companion species'. Are dogs really seen as Companion Species? That question is the primary focus of this study.

Human beings have become as busy as a bee, in mastering the laws of nature. This attitude is philosophically termed "anthropocentrism" where 'anthropos' in Greek means human beings and 'center' means core. Thus, anthropocentrism is the belief that considers human beings to be the most significant entity of the universe and interprets or regards the world in terms of human values and experiences. ${ }^{3}$ The individual, cultural and technological skills of humans have empowered them to a degree that no other specie has achieved, in the history of life on Earth.

\section{ANTHROPOCENTRISM}

The anthropocentric view of the world enables humans to view animals as inferior to them in the cosmic order. Such arguments have long exercised their influence on the thinking about animals in the history of sciences, Philosophers like Descartes and Kant views of animals are linked by an underlying logic that human beings have cognitive faculties which is missing in animals. This power has allowed humans to become the most successful species on the Earth. Perhaps this success is indicated by the rapidly growing population of human beings that is consuming the earth's resources for its sustenance.

During the Enlightenment or the Age of Reason, thinkers like Francis Bacon, Rene Descartes, John Locke and others emphasized the 'dualistic doctrine'. Descartes developed the philosophy of dualism based on Aristotle and Pluto, who were of the opinion that 'there exists multiple souls'.
But the former years later tried to affirm that 'the mind' and 'the body' are two separate entities. The mind has a consciousness or self-awareness, and since this intelligence is lacking in animals, human beings have an autonomy over animals.

To substantiate Descartes propaganda, Darwin's 'Origin of species' ignited scientific temperament among human beings. He discussed the evolution of species and explained how the modern human being was formed from the primitive ape. As science and technology developed, human beings understood and created an episteme. The understanding of magnetism, electricity, the maturation of chemistry as a new discipline with the discovery of carbon dioxide by Joseph Black, the discovery of sea routes, the developments in navigation and marine engineering or the growth in medical sciences etc added feathers on human civilization. That is to say, human beings enjoyed privileged status among all the living beings. Perhaps, anthropocentrism deals with this special, unique, central significance that human beings are privileged with.

But Kant claims that the world is shaped and sculpted by human cognitive skills and that it amounts to the humanization of metaphysics. It rests on the tautology that humans have no cognitive 'access' to the world except through their cognition of it, that whatever we know, perceive, understand, believe, imagine or say about the world depends on one's cognitive capabilities. The doctrine ignores the fact that, the world is cognized by non-human animals as well. In Kant's cosmopolitanism, human beings stand alone among earthly beings as capable of perfecting their natures and achieving the status of being "lords of nature".

Later in the age of imperialism, a human being of one particular ethnicity is superior to other was nourished. Imperialism advocated the concept self and other. When one thinks on similar line, it can be understood that human beings occupy the central position and animals occupy the margins. The marginalized status of animals makes them more gullible to human atrocities and exploitations.

Language nonetheless, gives an authoritative foothold for human beings. Say for example, words such as 'happiness'. Happiness is an emotion that is used to express feelings and experiences. These words are in themselves human and not platonic or divine. W.V. Quine is of the opinion that "words in a language are in accordance with necessary conditions and therefore their views cannot be captured in definition."5 Hence, the language used in the discourse of animals are themselves human and the inability of the animals to express in writing or speech excites humans to enjoy their supremacy. 
In the same sense, Panayot Butchvarov in his celebrated work Anthropocentrism in Philosophy investigates the epistemology that aids human beings to view and interpret everything in terms of human values and experiences. ${ }^{6}$ Thus, anthropocentric view proposes that humans are a natural component of earth's ecosystem and that humans have an absolute and undeniable requirement of the products and services of the ecosystem in order to sustain themselves and their society.

This anthropocentric perspective has caused much worry to environmentalists. The human impact on the ecosystem has caused a formal divide in the geological epoch. Thus, 'anthropocene' happens to be the study of this proposed epoch dating from the commencement of significant human impact on the Earth's geology and ecosystem. Nonetheless, 'anthropo' means man and 'cene' is new which means that human kind has caused the mass extinction of flora and fauna, polluted oceans, altered the atmosphere etc.

\section{NARCISSIM}

As opposed to the anthropocentric projection, in recent times Donna Haraway in 'When Species Meet' describes three great historical wounds to the primary narcissism of the self-centred human subject. First was the Copernican wound that removed Earth itself, man's home world from the centre of the cosmos and indeed paved the way for that cosmos to burst open into a universe of inhumane, nonteleological times and spaces. Science made that decentring cut. The second wound is the Darwinian, which put Homo sapiens firmly in the world of other critters, all trying to make an earthy living and so evolving in relation to one another without the sureties of directional signposts that culminate in man. Science inflicted that cruel cut too. The third wound is the Freudian, which posited an unconscious that undid the primacy of conscious processes. Science seems to hold that blade too.

The anthropocentric view on the contrary suggests that humans have greater intrinsic value than other species. A result of this attitude is that any species that are of potential use say, dog, cat, cattle etc can be a resource to be exploited. The use of animals occurs in an unsustainable fashion that results mostly in the degradation of biological resources. Many species today are at the verge of extinction like the leopard, baboons, the one horned rhino and many other species. Likewise the anthropocentric view also influences ethical judgments about the interactions with organisms. These ethics are often used to legitimize treating other species in ways that would be considered morally unacceptable if humans were to be treated similarly. Say, for example animals are often treated cruelly during normal course of events say in medical researches, agriculture, domestication of pets, taming horses for derby, circus or at a zoo. Apart from physical exhortion, the animals are emotionally wounded.

The anthropocentric perception is widespread and is considered to be responsible for severe environmental crisis ranging from global warming, ozone depletion and water scarcity to the loss of biological diversity. Deforestation for example, contributes to global warming where the trees logging means less absorption of carbon dioxide, thus leading to more greenhouses gases trapped in the atmosphere. A domino effect of such would lead to severe climate changes resulting in the extinction of various species due to habitat sabotage.

\section{LITERATURE REVIEW}

The concept of 'speciesism' plays a crucial role in drawing a line that separates animal world from humanity. 'Speciesism' is used to describe the distinction between humans and non-human animals. Psychologist Richard Ryder, in his essay Experiment on Animals (1971) used this word for the first time. He says "Speciesism" stands for human behaviour, which constitutes discrimination against animals. He elaborates that 'speciesism' overlooks or underestimates the similarities between the discriminator and those discriminated against and both forms of prejudice shows a selfish disregard for the interests of others and their sufferings. On the other hand cultural theorist Cary Wolfe believes that speciesism involves systematic discrimination against another based solely on a generic characteristic.

Animals have held an important place in literature hence animal fiction comes to mean fictional work where an animal plays an integral part of the story to make it complete. In most works of literature, animals function only in service to humans. They represent their human counterpart symbolically in order to teach lessons or correct human weakness. The anthropomorphism of animals has a long tradition in literature and can be dated to Aesop, a Greek storyteller from $6^{\text {th }}$ century BC. The many fables attributed to Aesop are moralistic stories that often feature animals as their protagonists, such as the well-known tale of 'Hare and the tortoise'.

With the Victorian era, animals have become more central to the human thoughts due to the revolutionary work of Charles Darwin in the field of animal taxonomy. But "in the twentieth century, the literal and figurative animals become particularly important in gender discourse and women's literature" says Mr. Mostafa. He is of the view that in these works however, the animals do not reflect the animals themselves but they are used to 
demonstrate some aspect of humanity. In simple words, the texts on animals are not all that animal-centric as they are not interested in the animals themselves but as subservient to the human master.

The literary establishment has always tended to consign novels about animals to children's fiction, mainly because of the more imaginative and open nature of a young audience. "The appeal of the animal kingdom and the anthropomorphism of creatures has always been something that delights children" is mentioned in Collins Classics. Perhaps one might wonder within animal centric literary texts appeal only to young readers and not adult readers? The fact it is that it is easier for children to access these stories because of the imaginative use of animals, but it is also a useful device for adults because it pares down or simplifies any characterization, and therefore the characters lose the complexity of human personality.

There have been numerous popular novels that feature an animal as the central character. Perhaps the best known example is Anna Sewell's Black Beauty, which tells the story of a horse from a quasi-engine point of view and it drew attention to the notion of animal mistreatment in the Victorian Age. In 1893 came a similar book titled Beautiful Joe by Margaret Marshall Saunders, this time from a quasi-canine perspective. There are a host of classical novels featuring animals as important characters such as George Orwell's Animal Farm, Richard Adam's Watership Down and Rudyard Kipling's The Jungle Book. In these novels, animals are given human behaviours and concerns and they are used to comment on human society as much as the animal world. Far fewer animal novels feature animals that remain purely animal.

Jack London's The Call of the Wild (1903) tells the story of a German shepherd named Buck. It is stolen from his owner and used as a sled dog. As an outsider to the sled pack, he is forced to fight all the time to stay alive. Finally, having come a tough, battle hardened survivor, he leaves the world of men entirely, living in the wild as a leader. A Scottish author Sheila Burnford published in 1961 a novel by name The Incredible Journey and Eric Knight, a British novelist published Lassie Come-Home in 1940. Both these novels deal with a long, arduous voyage back home to a much loved owner.

Through animal-studies the critics of recent times condemn the objectification of animals and emphasize that animals should be rather treated as subjects by recognizing their independence and asserting their agency. They encourage new writings that illustrates the non-human animal's unique otherness. These critics are sensitive according to Donovan to animal issues and have begun to theorize a new direction in literary criticism, an animal centric/animal standpoint criticism. Such a criticism seeks to examine works of literature from the point of view of how animals are treated therein, often looking to reconstruct the standpoint of the animals in question.

\section{ANALYSIS OF WHITE FANG}

Jack London was a proactive socialist as well as a writer. His work is allegorical in the sense that 'The Call of The Wild' may be interpreted as a treatise on moral and ethical conduct, along with it being an exploration of love and loyalty. The book shows how dogs have evolved as pack animals learning to bond and obey within a group. In the wild, wolves learn to carry favor within their pack in order to survive and breed within the females of the pack, thus passing their genes on to the next generation. These inclinations are so strongly imprinted that domestic dogs express them in their behavior towards human owner, and dog-owners interpret this natural instinct as love and affection.

The Call of The Wild has been adopted into various films and television adaptations. It is a tale that translates so well to different media as it is both straight forward and emotive. After experiencing genuine kindness from John Thorn and then losing him, Buck returns to the wild, and London's message seems to be that love, warmth and contentment should be appreciated as it is often short lived. He also shows that the struggle for survival is instinctual; as the story draws to an end, Buck has recovered his ancestral, primitive behavior and fully detached himself from the civilized world that he knew. The main conflict in all of his stories is man versus nature or dog-nature versus wolf nature. Although 'White Fang' is not human, the book illuminates the wolfish qualities of both men and animals, and the way humans shape other creatures.

First serialized in an American magazine and then published in 1906, the novel White Fang focuses on the domestication of a wild beast, a plot line which reverses the theme of Jack London's previous book, The Call of The Wild (1903). Set during the Klondike Gold rush of the 1890 s, one of the story's strengths is the author's ability to capture the brutal reality of survival in the wilds of the Yukon, Canada.

The eponymous main 'character' is part wolf, part dog and he eventually finds himself living among humans where his lot is only marginally better than in the harsh wilderness. A sense of alienation surrounds White Fang who is persecuted by wolves for being part dog and then by dogs for being part wolf. He becomes so toughened by the hostility of the world around him that he transforms 
into a vicious killer, an inevitable consequence of his instinct to survive.

Jack London anthropomorphized White Fang and the other animal characters giving them human personality traits and voices so that he could reflect on society and its failures without being overly moralistic, which would have been a natural consequence of using human, rather than animal characters. Social commentary aside, White Fang remains a well-loved tale comprising many twists and turns, highs and lows, friends and foes.

The story opens with two men Henry and Bill; they are out in the wild. They have seven dogs and they discover that their dogs keep disappearing. They soon learn that they are lured by a she-wolf and eaten by the pack. They only have three bullets left and Bill uses them to save one of their dogs. But he misses the shot and he is eventually killed along with one of the dogs. Henry is left with two dogs by the end of the day, he makes fire and tries to drive away the wolves. He is almost killed in this attempt when he is saved by a group of travellers who happen to pass by.

In the next part of the novel, the readers travel through the magnificent forests of the Northern America. The wolves return to the forest having missed the prey. They are starving. The she-wolf leads them along the famine stricken wild habitat. Their journey and hardship is beautifully narrated, London satirically presents the laws of nature. When the pack finally finds food, they split up. The pack is fragmented, the she-wolf, One-eye, a young cub and another wolf is all that is left. The wolves compete among themselves for the she-wolf. She-wolf finally mates with One-eye and she breed a litter of pups. The litter of pups is born in the midst of the famine and soon the famine becomes severe as a result of which many pups die and the she-wolf is left with just one pup. He grows up into a healthy, strong and active pup. One-eye dies, the she-wolf along with her pup are left in the den. She-wolf teaches her young one the tactics of hunting and survival. After much struggle, She-wolf finds her to the Indian camp.

In the third part, the readers learn that the she-wolf is Kiche who had run away from the Indian camp and had joined the pack of wolves during the mating season. Kiche is herself half dog and half wolf. After Henry and Bill, there is no description of the human-animal contact. London elucidates the wild habitat and the animal's survival strategies. At the camp, Grey Beaver, Kiche's master catches her. She is domesticated and their pup stays with her. He is named 'White Fang'. It so happens that Kiche and White Fang are distanced, as she is sold off to another man. While White Fang stays with Grey Beaver, he faces trouble at every turn. The other older dogs terrorize White Fang. He is all the time fear stricken but his wolfish nature makes him ferocious and aggressive. He soon loses the pup's innocence. Though domesticated, he is encouraged to be wild and terrorizing. As a result of this, White Fang is rather hostile and unfriendly. He kills other dogs and would get into fights very often. By the end of this section, the readers learn that White Fang is the star attraction among the traders and merchants. Grey Beaver is tricked and is forced to sell White Fang to Beauty Smith. $\mathrm{He}$ is the leader of the sled and he would tame the other dogs. He lived a life of royalty.

After much trouble, White Fang finally bids adieu to his former master and goes away with Beauty Smith. Beauty Smith is a heartless monster of a guy. He under-feeds White Fang, treats him cruelly. White Fang becomes more and more vicious. Smith uses his ferocity to make money. He organizes dog fights. He encourages White Fang to kill other dogs in the duo. People gather to witness the wolf like dog pounce over other dogs to make an easy victory. Beauty Smith collects money for his entertainment show and also encourage gambling in the name of White Fang. After being under a not so cruel Grey Beaver, Beauty Smith is a curse. White Fang loses the texture of his coat; he looks wilder than ever. One day when there is a fierce fight between White Fang and an English bulldog. White Fang has to fight an unequal combat. It's a 'do or die' situation and White Fang is already hurt and wounded badly. It is at the verge of death, at this moment, Scott, a gentleman who like a God-man comes to White Fang's aid. He saves him from the clutches of the bulldog and manages to buy him from Beauty Smith.

The last section of the novel deals with domestication of White Fang. The cruel, aggressive, ferocious nature of him is slowly transformed into that of a kind, loving, affectionate pet. He adapts to Scott who takes him to California with him. There he learns to love his master and his family. He befriends other dogs; his rather hostile nature is changed into a more amicable and friendly nature. He is a brave dog; he saves Scott's father from a criminal who had just escaped from the prison nearby. White Fang who mates with Collie and is seen with their puppies by the end. The novel closes with his troubled young age being modified into a cozy, comfortable adulthood. Ultimately, he wins the affection of Scott's family because of his extreme intelligence.

Jack London uses 'wild' as a symbol for the perilous nature of life. The wild symbolizes life as a struggle; say for example, the wild is a place in which, "the sun makes a futile effort to appear". White Fang himself is wild. The wild is, for White Fang as a pup, the 'unknown' and he in turn becomes the embodiment of the 'unknown' for the others. But the wild does not carry a negative connotation. 
Wilderness gives white Fang much strength and he experiences the joy of freedom and care-freeness. "He learnt quickly. It was in the nature of things that he must learn quickly, if he were to survive the unusually severe conditions under which life was vouchsafed him". London says "a constitution of iron and the vitality of the wild were White Fang's inheritance'. The Wild is thus a multivalent metaphor in White Fang. It tends to express the power of life to survive and thrive.

If the wild acts as a metaphor for freedom and joy, then light stands as a metaphor for life. There are constant references to the light and its flicker. In part II of the novel, the young pups starve and London skilfully uses light to express their hardship, "the life that was in them flickered and died down". Later, White Fang is left with just one sister, "flame flickered lower and lower and at last went out". The "wall of light is symbolic of a divide. The divide between the world of wolves and the rest of the world. Light therefore functions as a symbol of life and survival. The wall of light is thus a barrier that is both adventurous and risky. White Fang is time and again invited to travel through the 'wall of light'.

London is a naturalistic writer. Nature is personified and White Fang is anthropo morphed. The ideas of Darwinism dominates his writings. In the chapter, 'The Law of Meat', he furthers the idea of 'survival of the fittest'. It dwells on the conception 'eat or be eaten' the she-wolf kill the lynx's kittens, while One-Eye is killed by the Lynx. The novel stands for exploitation of the powerless and for human cruelty. Beauty Smith is a dog fighter. White Fang's life under him is pitiable. "That man was ominous with evil, pregnant with hurtfulness and therefore a thing bad, and wisely to be hated". He is a monstrous being. He underfed and tortured White Fang to the maximum extent. He leaves him in a cage, "White Fang raged and snarled at the men who surrounded the cage, the studied them with cold hatred as he lay in a corner" (IV.3). Life had become a hell. He was not been made for close confinements like wild beasts in zoo, endure at the hands of men. It was precisely, the same way that he was treated. "Men stared at him, poked sticks between the bars to make him snarl and they laughed at him." The cruelty of human beings is well portrayed. London's narrative style is refreshing and heartwarming. The strength and vigor White Fang possesses is attributed to Nature. "Nature had given him plasticity. Where any other animal would have died or had it spirit broken. But White Fang adjusted himself and lived.'

Dogs are used to carry carts in many temperate places, sledge carts of Eskimos are drawn by long haired dogs. Like it is seen in the pictures of Santa Claus. White Fang is the sled leader. "About his neck was put a moss stuffed collar which was connected by two pulling traces to a strap that passed around his chest and over his back. It was to this that was fastened the long rope by which he pulled at the sled. There were seven puppies in the team". The utility of dogs for transportation and goods carriers was a common sight during the American gold-rush. London thereby sketches the various utilities of dogs. He hence invites the readers to excavate the methods of domestication and utility. He describes animal behavior and psychology subtly. The competition between White Fang and Lip-Lip, or White Fang's wild attitude to boss over other pups are instances through which London tries to develop a cosy world of dogs.

Donna Haraway is of the opinion that dogs are companion beings. But Jack London details on Grey Beaver and Beauty Smith is in contestation with this notion. Grey Beaver sells White Fang to Beauty Smith and this beast of a person makes huge profit by confining White Fang in a cage and exhibiting him as an artefact. White Fang's emotions are not paid attention. His feelings are mechanised and he is commoditised. When finally he accepts Grey Beaver as his master, he changes hand and Beauty Smith becomes his new master. After much hardship and torment White Fang finds a loving, caring and an affectionate master in Scott. Dogs are just like other species. They find it difficult to acclimatise themselves to new environments and among new people. White Fang takes time to accept Scott as his master but with the help of Dick and Collie, he accommodates himself to the new family. Haraway projects dogs as extremely sensitive and socialite. White Fang happens to be highly protective of his master and his family. While he saves Scott's father, he bares three bullets and is badly injured. With proper care, love and attention White Fang recoups. Nevertheless, Haraway's notion of seeing animals on par with human beings give rise to companion beings who share a sacred bond.

Haraway tries to de-construct the idea of dogs being the other or inferior to human beings. She notes Derrida's observations in her work When Species Meet. She says, Derrida correctly criticised two kinds of representations, one set from those who observe real animals and write about them but never meet their gaze, and the other set from those who engage animals only as literary and mythological figures. This is to say that one comes across a dog, looks at it but one forgets that this dog also looks back to us. She is thereby trying to distinguish the act of seeing and looking. One is reminded of H. D. Thoreau who once said 'It's not what you look at that matters, it's what you see". Similarly, she invites readers to understand the fact that dogs are companion species which 'respond and react' and therefore yearn for respect. With such perceptions one can understand White Fang to be a 
portrayal of beings that co-shape themselves and reciprocate the treatment of human beings. One realises that appreciating them and their distinctive character is a pre-requisite for accommodating them as 'companion species'.

\section{CONCLUSION}

The study mediates the intersections between the humankind and dogs, philosophy and science, and macro and micro cultures. The idea of companion species reassures that dogs are much more than companion animals. Donna Haraway digs into this larger phenomenon to contemplate the interactions of humans with many kinds of critters, especially with those called domestic. White Fang and Antis go out of their way to save their masters. These dogs are therefore beings that react, respond and reciprocate. Animals are otherwise considered inferior to human beings as they lack cognitive skills. But the study leads to a realization that all species have crucial roles to play in the environment. The condescending attitude of human beings has altered food chains and has endangered biodiversity. The project thus initiates a peaceful coexistence and discusses the important role animals play in the world. Dogs are indeed a companion species and they are to be seen on par with human beings.

White Fang aestheticizes dog. Although the novels adopt an animal viewpoint to emphasize the experiences, feelings and consciousness to render $\operatorname{dog}$ s as equal to human beings, Mr. Mostafa is of the notion that "writer's emphasis on thinking through the concept of humananimal material relationship is indispensable for grasping what animals mean to humans". This according to the study is because the concept animal has been the basis for the furthering of the idea of 'human'. This is also because it makes human beings conscious of their attitude towards other species. However, the project has enabled one to be critical of the role literature plays in ethical and intellectual life. The work tries to convey some truths about dogs and inter-species relations. Thus, bonds with other species are essential for human survival gets clarified. This study also encourages further study in the field of animal-centric criticism. It puts forth the idea that dogs are not merely species that share earth-space. Thus, "The Canine in Literature" forwards the idea of inclusive living.

\section{ACKNOWLEDGEMENTS}

I am indebted to my parents for their tacit support extended during the course of study.

\section{REFERENCES}

[1] Haraway D (1991). "A Cyborg Manifesto: Science, Technology, and Socialist-Feminism in the Late Twentieth Century." In Simians, Cyborgs and Women: The Reinvention of Nature. New York: Routledge.149-181.

[2] Mostafa Mohammed Hosny. 2015. The Animal Turn in Fiction: An Animal Centric Analysis of 'A Dog's Purpose' and 'Anthill'. International Journal of English and Literature. Vol 6 (9) pp 150-162.

[3] Derrida J (2008). The Animal That Therefore I am. Ed. Marie-Louise Mallet. Trans. David Wills. NewYork: Fordham University Press.

[4] Donovan J (2009). "Tolstoy`s Animals." Society and Animals. Accessed on 28 November 2020.

[5] DeMello M. 2012. 'Animals and Society: An Introduction to Human-Animal Studies'. New York: Columbia University Press Print.

[6] London, Jack. 2014. White Fang. Great Britain. William Collins.

[7] Badmington N (2011). "Posthumanism." Routledge Companion to Science and Literature.

[8] Clarke B (2008). Posthuman Metamorphosis: Narrative and Systems. New York: Fordham University Press.

[9] Haraway D (1991). "When Species Meet." University of Minnesota Press: Minnesota.

[10] Braidotti R.(2013). The Posthuman. Cambridge, UK: Polity Press. 